\title{
BIBLICAL DRAMA \\ UNDER THE TUDORS
}

by

RUTH H BLACKBURN

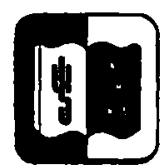

1971

MOUTON

THE HAgUe - PARIS 
(c) Copyright 1971 in The Netherlands.

Mouton \& Co. N.V., Publishers, The Hague.

No part of this book may be translated or reproduced in any form, by print, photoprint, microfilm, or any other means, without written permission from the publishers.

LIBRARY OF CONGRESS CATALOG CARD NUMBER: 70 - 106467

Printed in The Netherlands by Mouton \& Co., Printers, The Hague. 
To my father

and

to the memory of

my dear mother 
